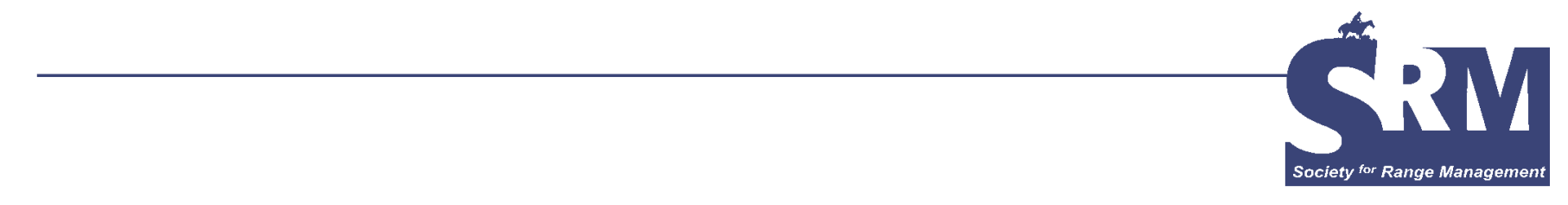

\title{
Native American Management and the Legacy of Working Landscapes in California
}

\section{Western landscapes were working long before Europeans arrived.}

\section{By Lucy Diekmann, Lee Panich, and Chuck Striplen}

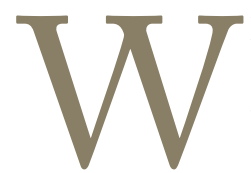

hen the Spanish first settled in California in 1769 , they entered the homeland of more than 300,000 California Indians whose ancestors had inhabited the region for at least 12,500 years. ${ }^{1,2}$ These Native Californians were some of the millions of native people living in every part of the continent at the time of contact with Europeans. Yet the idea that the original American landscape was unworked land is persistent and widespread. It colors our relationship to the historical landscapes of North America, particularly those protected in our state and national parks. Because these parks were envisioned as places where people do not live and work, the Indians who lived there had to be removed in order to create these "pristine" landscapes. ${ }^{3,4}$ The resulting park landscapes do not represent islands of pristine nature, but a historically unprecedented creation - a radical departure from the past. ${ }^{5}$ Over the past century and a half, national parks have helped to define American ideals about the human relationship to nature. In this model, people are removed from nature, becoming spectators rather than active participants.

This idea also affects how resource managers and the public-at-large view other public and private lands. The belief that American Indians did not have a significant effect on the natural world they inhabited thus has important implications for native people and non-Indians alike. Ignorance of

This article has been peer reviewed. the influences and needs of American Indians was once an excuse for ignoring territorial claims and curtailing traditional management practices. In addition, this attitude reinforces the idea that humanity's original relationship to nature does not involve work. This notion is integral to the belief that Euro-Americans arrived in a wild Eden and experienced a "fall from grace" once they began to work the land. ${ }^{6}$ EuroAmericans' work in the environment is seen as the beginning of environmental degradation in North America, and the amount of work is believed to be directly proportional to the amount of degradation. Although both Natives and modern agriculturists certainly have the potential to negatively affect the environment, the pervasive and incorrect notions about how Natives lived is the opening act in a story that continues to impact ranchers and others today.

The "working landscape" idea is an important counterpoint to this narrative of inevitable environmental decline. The standard story that links work to environmental degradation does not leave room for people working responsibly with nature, nor does it allow for the possibility that productive work might enhance ecosystem health. Working landscapes represent an alternative model of people's relationship to nature. Between the extremes of nonuse and abuse there exists a middle ground where productive uses and environmental benefits can coexist.

Understanding Native management practices and their effects is an important starting point for the working landscape model. American Indians used a wide array of natural 
resources for food, medicines, raw materials, and ceremonial regalia. Although acorns, salmon, and large game are often highlighted as staples of the California Indian diet, ethnographic research, archaeological research, and tribal oral histories have shown that Natives in the Golden State actively used over 500 different plant and animal species. ${ }^{7,8}$ In order to increase the quality, availability, and predictability of these materials they manipulated ecosystems through burning, pruning, weeding, and other means. ${ }^{9,10}$ Management required knowledge of ecosystems and species and their responses to a variety of factors, such as season and rainfall, as well as their responses to various human disturbances.

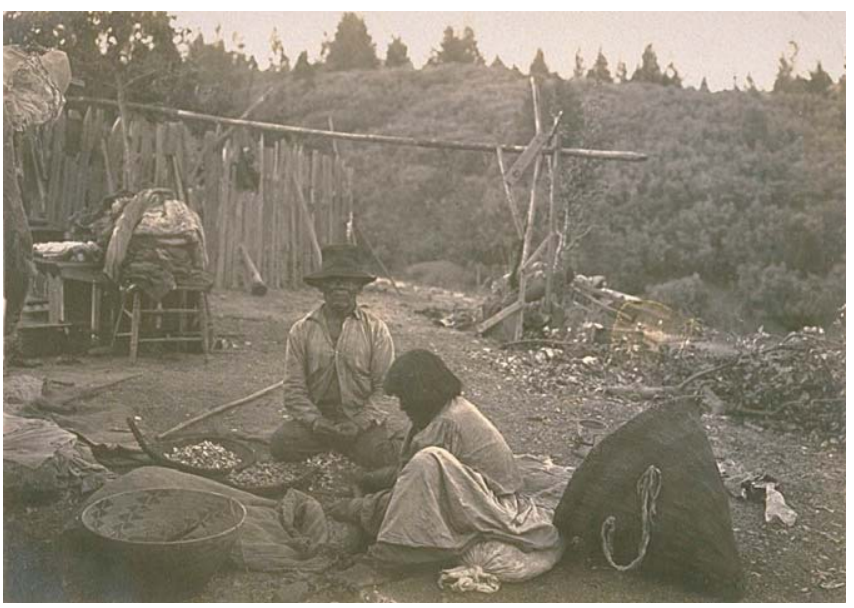

California Indian couple (Yankee Jim and an unidentified woman) shucking acorns in Placer County, California, taken 8 September 1902. Note the large gathering baskets in the foreground, which were still being made into the mid-20th century. Photograph courtesy of the Bancroft Library, University of California, Berkeley.

Burning was the Native Californians' most important and effective land management tool. Like pruning and weeding, it could be used to improve the quality and vigor of individual plants or of particular stands. On a broader scale, it could also be applied to manage plant communities and landscapes. California Indians used fire to increase the abundance of particular plant species, to shift the balance between different plant communities, and to maintain a landscape of diverse resource patches. Other uses of fire included facilitating travel, reducing the risk of large fires by reducing fuel loads, increasing animal forage, and even distributing animal forage across the landscape to control populations. Fire served many purposes, but the overall result was increased landscape diversity, heterogeneity, and productivity. ${ }^{11}$

As an example of the ecological knowledge and active management used to manage ecosystems, consider basketry. Basketweavers need roots, branches, and shoots that are long, straight, and supple; but left to grow "wild," many important plant species can grow to be brittle or crooked. To obtain the characteristics they desired, Native Californians used coppicing, pruning, digging, transplanting, weeding, removing debris, and burning. For example, to encourage the growth of long, straight twigs that could be used for basket material, willows (Salix sp.) might be coppiced-an intense form of pruning-during the dormant season. To ensure new growth of tule (Schoenoplectus sp.), another important and versatile plant, burning was used after summer harvest to remove old growth and allow space for new growth. This action also maintained edge complexity around ponds, lakes, and sloughs that served other taxa as well. Without burning, a thick mat of dead tules, which decompose slowly, quickly accumulates and blocks out the sunlight needed by new shoots. Imagine the steady supply of plant materials needed to meet the demand for basketry materials, when a single cooking basket, for instance, uses approximately 3,750 stems, or the output of more than 37 bunchgrass plants. Similarly, a single deer net required as many as 35,000 stalks from milkweed or dogbane..$^{8,9,12}$

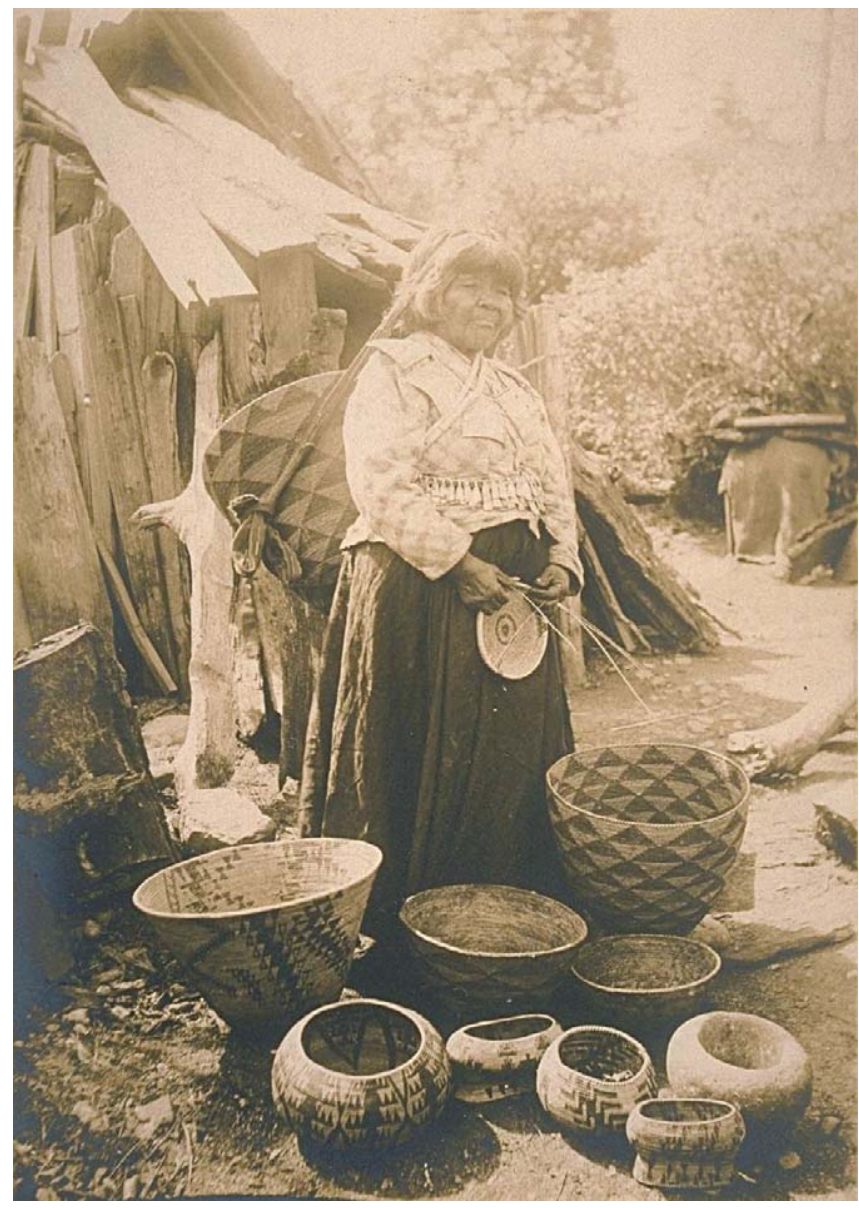

California Indian woman with baskets taken at Hank's Exchange in El Dorado County, California (date unknown). This image nicely illustrates the diversity in size, style, and materials used in basket construction by a single Native weaver in early 20th-century California. Photograph courtesy of the Bancroft Library, University of California, Berkeley.

At a larger scale, Native Californians also managed the composition of landscape patches. They managed the "proportionality" of resource patches to enhance the abundance of desired plants and to reduce the numbers of less desirable spe- 
cies. In coastal areas, for instance, California Indians burned, and possibly removed by hand, salt marsh coyote brush (Baccharis spp.), which was not needed in large quantities, in order to prevent it from crowding out other valuable species such as willow and sedge. Further from the coast, managing proportionality could entail burning to impede the encroachment of trees and woody shrubs into grasslands. ${ }^{9}$ Also, in the shrublands of the coast ranges, Indian burning altered vegetation patterns, converting predominantly evergreen chaparral and coast sage scrub shrublands into a mosaic of open shrublands and grasslands. ${ }^{13}$

Over a period of many thousands of years, California Indians developed management practices that were well-suited to the natural diversity of the environment. It is important to remember, however, that these management systems were not static. Many people who recognize California Indians' profound role in shaping the state's ecosystems often assume that before the disruption of the colonial period and its aftermath, the state's original inhabitants lived in a stable, harmonious balance with nature. ${ }^{14}$ There are several reasons why this characterization is inaccurate. First, Native Californian management was well suited to the Californian environment precisely because it could accommodate variability in productivity from place to place, season to season, and year to year. ${ }^{8,11}$ Second, climate change altered the distribution of vegetation communities, on shorter (eg, El Niño) and longer time scales. In addition, ecosystems in California are occasionally subject to larger, less predictable events; earthquakes and flooding have the power to cause dramatic changes within habitats, and dendrochronological evidence shows that large, catastrophic fires occasionally swept through precolonial ecosystems. ${ }^{15} \mathrm{In}$ addition to responding to these ecological changes, California Indians continued to innovate, developing new practices and techniques that shifted their relationship to and effect on the local landscape.

In sum, California Indians developed a system of management that was designed to influence the productivity and abundance of particular plants and animals. Unlike farmers who often focus their efforts on the scale of plot or field, California Indians used fire to affect productivity and diversity across the broader landscape. By burning certain ecosystems at different intervals they created a patchwork of diverse habitats. The resulting mosaic of habitats maintained at different stages of succession provided a wide range of resources for Indians' use and consumption. Not only did a diverse resource base provide a nutritious diet, it also gave California Indians greater flexibility and choice, buffering them against periods when certain resources were unavailable. Managing at the landscape scale was a strategy particularly well-suited to California's environment where productivity varies greatly over space and time. ${ }^{8,11}$ Consequently, the landscapes that European colonists encountered and that Californians prize today are not solely the product of ecological and geological processes. Instead their form and function were the result of a mix of human intervention and natural processes. Rather than think of precolonial landscapes as wilderness, it is more accurate and more useful to think of them as cultural landscapes, and perhaps working landscapes, in which human use also has the potential to enhance ecosystem productivity and diversity.

\section{Case Study: Año Nuevo State Park}

Although it is generally agreed that the precolonial landscapes of California were both natural and cultural creations, less is known about the exact nature and extent of Native influence. Contemporary land managers and restoration ecologists could benefit from knowledge of the methods and the botanical communities modified through cultural activities over long time periods, but this requires research that specifically addresses landscape history and Native management practices. Currently one such project is under way in Año Nuevo State Park in southwestern San Mateo County, California, approximately 55 miles south of San Francisco. Like other undeveloped places, the park no longer resembles what it was when the Quiroste Band of Ohlone Indians occupied this stretch of California's coastline. To understand the nature of the changes that have taken place since the functional removal of the Quiroste from the California Central Coast, and to reconstruct a model of Quiroste resource management, requires a multidisciplinary approach at various temporal and spatial scales.

Beginning in summer 2007, this interdisciplinary research project will test the hypothesis that precolonial peoples served as "ecosystem engineers," a concept that incorporates people as participants in natural communities. It is expected that the removal of these ecosystem engineers had significant and measurable effects on landscape form and function. ${ }^{16}$ The particular foci of this research are determining the role of fire in maintaining specific habitats and the consequences of removing Indian burning.

Although it is relatively easy for people studying California Indians to uncover evidence of pre-colonial occupation, it is much more difficult to discover how past landscapes appeared and were used. Tribes in California had no written language, nor did they produce pottery or (at least in this region) large dwellings that could be examined. Because much of California Indian material culture was constructed primarily of plant material, researchers need to expand the breadth of their analyses to include microbotanical and even isotopic tools. Methods drawn from archaeology, landscape ecology and history, and paleoethnobotany will be used to ascertain how the Quiroste maintained and modified coastal grassland and oak woodland habitats. Historical ecology methods that draw on early maps, documents, and photographs will be used to characterize the landscape changes that have taken place since colonization, which took place around 1770 in this locale. Archaeological and paleoethnobotanical sources will provide information about diet and subsistence. Information about the resources that were being used can then be combined with fire scar date, climate reconstructions, and the natural history attributes of key, culturally-managed spe- 
cies to generate a localized, seasonally-focused management regime for this area.

\section{Historically Managed Landscapes Today: Les- sons for Contemporary Ecosystem Managers}

California's iconic oak woodlands, coastal prairies, and montane meadows were regularly used and frequently burned by Natives as recently as the 1850 s. $^{12,17-19}$ Many western ecosystems, including California rangelands, were shaped by the work American Indians did to make their local environments produce needed food and raw materials. These practices created, maintained, and enhanced distinctive habitats. Removing Natives from their role as ecosystem managers, and failing to recognize the role of "work" in shaping those ecosystems, has had far-reaching ecological consequences, as the project at Año Nuevo State Park seeks to demonstrate.

Recognizing that many of the ecosystems that so impressed early explorers and settlers were actually anthropogenic landscapes can help contemporary land managers and conservationists see that excluding human activity might not have the desired consequences. The realization that people played an important part in shaping certain distinctive ecosystems - and that their work in nature oftentimes maintained and enhanced natural diversity — can suggest alternate ways of protecting landscapes and resources. Rather than achieving protection by removing productive human activities-activities which are not recreational or leisure-basedmanagers might consider protecting valued landscapes and habitat characteristics through use and work. The hunting, gathering, and burning practices of Native people can expand the types of productive uses that might benefit both people and landscapes. Although acknowledging that active human use and management has the potential to have positive environmental outcomes makes environmental decision-making more complicated, it also offers more options.

It is equally important to remember that American Indian managers and management are not a thing of the past. Today there are roughly 150,000 Native Californians living in selfgoverning Indian communities, cities, farms, and ranches. For these people, the plant and animal resources that were used historically for food, raw materials, medicines, and ceremonial purposes remain important. Modern tribes are involved in resource management both on and off reservations, at the local, regional, and national levels. Groups such as the California Indian Basketweavers Association, the Native American Traditional Plant Coalition, the Native American Fish and Wildlife Society, and the National Tribal Environmental Council, are actively involved in protecting and maintaining culturally important natural resources. Drawing on traditional ecological knowledge and restoring traditional management is not just an opportunity to rehabilitate ecosystems, but also a chance to strengthen cultural practices and to build political relationships with contemporary Tribes.

In 1894, when John Muir coined the term "range of light," he was referring to the open, fire-resistant woodlands of Yo- semite and the forests of the Sierra Nevada. From the late 19 th century into the mid-20th century, western ranchers frequently burned brushlands to open them up for grazing and to reduce fire hazard. In the intervening decades, however, resource managers instituted fire suppression policies and simultaneously suppressed native and agriculturalist burning. Over the same period, a host of other indigenous management practices became impossible as Native populations lost land and declined in population. As a result, shrubs and trees have encroached on open meadows and tremendous fuel loads have accumulated in the forests and rangelands of the West, often with disastrous effects. This current situation is due in part to our standard model of environmental degradation, which is premised on the American landscape being unmodified wilderness at the time of European contact. By better understanding the original working landscapes of the West's original inhabitants, we can start to see the historically and culturally dynamic nature of ecosystems. A more inclusive and comprehensive story of how landscapes have been managed offers a range of new management alternatives and practices as well as the opportunity to establish mutually beneficial relationships with American Indian tribes.

Authors are PhD Candidate, Department of Environmental Science, Policy, and Management, 137 Mulford Hall MC 3114, University of California-Berkeley, Berkeley, CA 94720-3114, diekmann@nature.berkeley.edu (Diekmann); PhD Candidate, Department of Anthropology, University of California-Berkeley, Berkeley, CA 94720 (Panich); Amah Mutsun Tribal Band, PhD Candidate, Department of Environmental Science, Policy, and Management, University of California-Berkeley, Berkeley, CA 94720 (Striplen).

\section{References:}

1. Moratto, M. J. [ed.].1984. California archaeology. Orlando FL: Academic Press. 757 p.

2. Arnold, J. E., M. R. Walsh, and S. E. Hollimon. 2004. The archaeology of California. Journal of Archaeological Research 12(1):1-73.

3. Spence, M. D. 1999. Dispossessing the wilderness: Indian removal and the making of the national parks. New York, NY: Oxford University Press. $190 \mathrm{p}$.

4. JАсову, K. 2001. Crimes against nature: Squatters, poachers, thieves, and the hidden history of American conservation. Berkeley, CA: University of California Press. 305 p.

5. CRonon, W. 1995. The trouble with wilderness, or, getting back to the wrong nature. In: W. Cronon [ed.]. Uncommon ground: Toward reinventing nature. New York, NY:W.W. Norton. p 69-90.

6. White, R. 1995. Are you an environmentalist or do you work for a living? In: W. Cronon [ed]. Uncommon ground: Toward reinventing nature. New York, NY: W.W. Norton. p 171-185.

7. Heizer, R. F., ANd A. B. Elsasser. 1980. The natural world of the California Indians. Berkeley, CA: University of California Press. $271 \mathrm{p}$. 
8. Lightfoot, K. G., and O. Parrish [eds.]. in prep. The diverse worlds of the California Indians. Berkeley, CA: University of California Press.

9. Striplen, C. J. 2006. Life and times at the edge of the bay. News from Native California 20(1):24-25.

10. Sнipeк, F. C. 1989. An example of intensive plant husbandry: the Kumeyaay of Southern California. In: D. R. Harris and G. C. Hillman [eds.]. Foraging and farming: The evolution of plant exploitation. London, UK: Unwin Hyman. p 159-180.

11. Huntsinger, L., and S. McCaffrey. 1995. A forest for the trees: Euro-American forest management and the Yurok environment, 1850 to 1994. American Indian Culture and Research Journal 19(4):155-192.

12. Anderson, M. K. 2005. Tending the wild: Native American knowledge and the management of California's natural resources. Berkeley, CA: University of California Press. 526 p.

13. Keeley J. E. 2002. Fire management of California shrubland landscapes. Environmental Management 29:395-408.

14. Preston, W. 1998. Serpent in the garden: environmental change in colonial California In: R. A. Guiterrez and R. J. Orsi. [eds.]. Contested Eden: California before the gold rush.
Published in association with the California Historical Society, Berkeley, CA: University of California Press. p 260-298.

15. Stephens, S. L., And D. L. Fry. 2005. Fire history in coast redwood stands in the northeastern Santa Cruz Mountains, California. Fire Ecology 1(1):2-19.

16. Striplen, C. J. 2005. A proposal to the Ford Foundation-the ecological role of pre-colonial peoples in central coastal California: Observations on ecosystem management. Berkeley, CA: University of California. 8 p.

17. Bean, L. J., and H.W. Lawton. 1973. Some explanations for the rise of cultural complexity in Native California with comments on proto-agriculture and agriculture. In: T. Blackburn and M. K. Anderson [eds.]. Before the wilderness: Environmental management by Native Californians. Menlo Park, CA: Ballena Press. p 27-54.

18. Blackburn, T., and M. K. Anderson [eds.] 1993. Before the wilderness: Environmental management by Native Californians. Menlo Park, CA: Ballena Press. 476 p.

19. Lewis, H. T. 1973. Patterns of Indian burning in California: ecology and ethnohistory In: T. Blackburn and M. K. Anderson [eds.]. Before the wilderness: Environmental management by Native Californians. Menlo Park, CA: Ballena Press. p 55-116. 